\title{
HUBUNGAN FAKTOR INTERNAL DENGAN KELELAHAN SUBJEKTIF PEKERJA
}

\author{
Mustofani \\ Keselamatan dan Kesehatan Kerja, Universitas Airlangga \\ Email: mustofani-2016@fkm.unair.ac.id
}

\begin{abstract}
Work-related fatigue can be defined as mental or physical fatigue that occurs due to prolonged activities that can reduce a person's ability to do work safely and effectively. The prevalence of reported work-related fatigue varies from $10 \%$ to $40 \%$. Work-related fatigue is a problem that needs to be solved immediately because it can have an effect on the incidence of workplace accidents, can reduce production rates and have a negative impact on workers' health. Work-related fatigue is influenced by internal factors (including age and nutritional status) and external factors of workers. This study was an analytic observational study with cross-sectional research design. The number of respondents in this study reached 30 workers. The independent variabels in this study were age and nutritional status. While the dependent variabel in this study is subjective work-related fatigue. Age variabels and subjective work-related fatigue were measured using a questionnaire and nutritional status variabels were measured using the Body Mass Index (BMI). The purpose of this study was to determine the relationship between age and nutritional status with subjective work-related fatigue experienced by workers. After analyzing the data and doing statistical tests using the Spearman correlation test, the p-value value between the variabels of age and subjective work-related fatigue was 0.332 and the variabel nutritional status with subjective work-related fatigue was 0.716 . The conclusion that can be taken in this study is there is no relationship between age and nutritional status with subjective work-related fatigue of workers.
\end{abstract}

Keywords: Age, Nutritional Status, Subjective Work-Related Fatigue

\begin{abstract}
ABSTRAK
Kelelahan kerja dapat diartikan sebagai keadaan lelah mental atau fisik yang terjadi akibat aktivitas yang berkeanjangan yang dapat mengurangi kemampuan seseorang untuk melakukan pekerjaan dengan aman dan efektif. Prevalensi terjadinya kelelahan kerja yang telah dilaporkan bervariasi dari $10 \%$ hingga $40 \%$. Kelelahan kerja merupakan permasalahan yang perlu segera diatasi karena dapat berpengaruh pada timbulnya kecelakaan kerja, dapat menurunkan angka produktifitas dan berdampak negatif pada kesehatan pekerja. Kelelahan kerja data dipengaruhi faktor internal (termasuk usia dan status gizi) dan faktor eksternal pekerja. Penelitian ini merupakan penelitian observasional analitik dengan desain penelitian cross sectional. Jumlah responden dalam penelitian ini mencapai 30 pekerja. Variabel independen dalam penelitian ini adalah usia dan status gizi. Sedangkan variabel dependen dalam penelitian ini adalah kelelahan subjektif. Variabel usia dan kelelahan subjektif diukur dengan menggunakan kuesioner dan variabel status gizi diukur dengan menggunakan Indeks Masa Tubuh (IMT). Tujuan penelitian ini adalah untuk mengetahui hubungan antara usia dan status gizi dengan kelelahan subjektif yang dialami pekerja. Setelah dilakukan analisis
\end{abstract}


data dan dilakukan uji statistik dengan uji korelasi Spearman didapatkan nilai p-value antara variabel usia dan kelelahan subjektif adalah 0,332 dan antara variabel status gizi dengan kelelahan subjektif adalah 0,716 . Kesimpulan yang dapat diambil dalam penelitian ini adalah tidak ada hubungan antara usia dan status gizi dengan kelelahan subjektif pekerja.

Kata kunci: Usia, Status Nutrisi, Kelelahan Subjeki

\section{PENDAHULUAN}

Seiring dengan berkembangnya zaman, pertumbuhan di sektor industri skala besar dan sedang di Indonesia juga mengalami peningkatan. ${ }^{1}$ Pertumbuhan tersebut mendapat respon positif dari pertumbuhan tenaga kerja di Indonesia. Pertumbuhan tenaga kerja dari tahun 1990 hingga 2016 terus mengalami pertumbuhan. Meskipun fluktuatif, pertumbuhan tenaga kerja di sektor industri rata-rata mencapai $4 \%$ per tahun pada periode tersebut. Selama tahun 2009 hingga 2016, untuk setiap 1\% pertumbuhan di sektor industri, pertumbuhan ketenagakerjaan meningkat sebesar $0,79 \%{ }^{2}$

Peningkatan jumlah industri dan tenaga kerja dengan otomatis diikuti dengan peningkatan risiko terkait masalah kesehatan dan keselamatan kerja di tempat kerja. Masalah yang sering dijumpai ditempat kerja salah satunya adalah terjadinya kelelahan kerja. Prevalensi kelelahan kerja yang telah dilaporkan bervariasi dari $10 \%$ hingga $40 \%{ }^{3}$

Kelelahan kerja dapat diartikan sebagai keadaan lelah mental atau Lelah fisik yang terjadi akibat aktivitas yang berkepanjangan, yang dapat mengurangi kemampuan seseorang untuk melakukan pekerjaan dengan aman dan efektif. $^{3}$
Permasalahan terkait kelelahan kerja harus dapat diselesaikan. Selain dapat berpengaruh pada keselamatan ditempat kerja dan menurunkan angka produktivitas kerja, kelelahan kerja jangka panjang juga dapat berdampak pada kesehatan pekerja. Beberapa risiko kesehatan yang dapat terjadi sebagai akibat kelelahan kerja yang berkepanjangan antara lain penyakit jantung, diabetes, tekanan darah tinggi, gangguan pencernaan, penurunan tingkat kesuburan, kecemasan, dan depresi. ${ }^{3,4}$

Dalam teori keseimbangan ergonomi, kelelahan kerja terjadi akibat kondisi overstress, yaitu keadaan dimana tuntutan tugas yang diterima pekerja lebih besar dari kapasitas kerja yang dimilikinya. ${ }^{5}$ Dalam melakukan pekerjaan, terdapat beberapa faktor yang memengaruhinya yaitu faktor internal dan faktor eksternal pekerja. Beberapa hal yang termasuk kedalam faktor internal antara lain usia dan status gizi pekerja. ${ }^{4}$

Faktor internal tersebut sangat enting untuk diperhatikan karena faktor tersebut tidak bisa dipishakan dari diri pekerja. Usia merupakan faktor yang tidak bisa diabaikan karena usia memiliki pengaruh terhadap kekuatasn fisik dan psikis sesorang. ${ }^{4}$ Penelitian yang dilakukan pada pekerja pekerja di bagian loining PT. Sinar Pure Foods Internasional 
Bitung, ${ }^{6}$ pada pekerja konveksi bagian penjahitan di CV. Aneka Garment Gunungpati Semarang, ${ }^{7}$ Pada tenaga kerja bongkar muat di Pelabuhan Samudera Bitung, ${ }^{8}$ dan pada pekerja di PT. X di Jakarta, ${ }^{9}$ menyatakan adanya hubungan yang signifikan antara usia pekerja dengan terjadinya kelelahan kerja yang terjadi pada pekerja.

Status gizi memiliki pengaruh yang penting terhadap kinerja yang dilakukan pekerja. Kapasitas kerja seseorang dapat terganggu ketika kebutuhan energi baik secara kualitatif maupun secara kuantitatif tidak tercukupi. ${ }^{10}$ Penelitian yang dilakukan pada pekerja pekerja di bagian Loining PT. Sinar Pure Foods Internasional Bitung, ${ }^{6}$ pada pekerja bagian weaving di PT. Iskandar Indah Printing Textile Surakarta, ${ }^{11}$ pada pekerja PT. Multi Aneka Pangan Nusantara Surabaya ${ }^{12}$, menyatakan adanya hubungan yang signifikan antara status gizi yang dengan kelelahan kerja yang dialami pekerja.

\section{METODE PENELITIAN}

Penelitian ini dilakukan selama 5 hari kerja terhitung tanggal 15 oktober 2018 di area fabrikasi PT. Bangun Sarana Baja Gresik Workshop. Penelitian ini merupakan penelitan dengan desain observasional analitik dengan desasin penelitian cross sectional. Penelitian ini dilakukan pada 30 responden yang dipilih secara acak menggu-nakan metode simple random sampling.
Peneliti membuat daftar nama pekerja dan dilakukan pengundian untuk menentukan pekerja mana yang terpilih menjadi responden. Kriteria inklusi yang ditetapkan dalam penelitian ini antara lain responden tidak memiliki riwayat penyakit hypothyroid, hepatitis, tuberculosis, nyeri kronis, penyakit jantung, kanker, dan diabetes serta responden bersedia terlibat dalam penelitian tanpa ada paksaan dari pihak manapun.

Pengukuran variabel usia dilakukan dengan menggunakan alat bantu kuesioner. Usia didefinisikan sebagai lamanya hidup responden dari lahir hingga penelitian dilakukan dalam satuan tahun. Variabel usia didalam penelitian ini dibagi menjadi dua yaitu usia $\leq 35$ dan usia $>$ 35. Penentuan ini berdasarkan titik puncak kapasitas kerja maksimum yang dimiliki seseorang. ${ }^{4}$

Pengukuran varibel status gizi dilakukan dengan menggunakan Indeks Masa tubuh (IMT). Metode ini dipilih karena memiliki beberapa kelebihan diantarnya pengukuran paling ideal dan akurat, biaya yang diperlukan tidak banyak, perhitungan sederhana, dan tepat digunakan pada responden dewasa. ${ }^{13}$ Hasil perhitungan kemudian dikategorikan menjadi kurus $(\mathrm{IMT} \leq 18)$, Normal $(\mathrm{IMT}=18-24)$, Gemuk $($ IMT $=25-30)$, dan Obesitas $($ IMT $\geq$ 35). ${ }^{14}$

Pengukuran variabel kelelahan kerja diukur secara subjektif dengan menggunakan instumen dalam bentuk kueseioner yang berisi 
skala pengukuran kelelahan (SPK) yang disusun berdasarkan Fatigue Assesment Scale (FAS). Instrumen ini dipilih karena sudah dilakukan pengujian pada 108 responden oleh Zuraida and Chie (2014) dan memiliki tingkat kehandalan yang baik. ${ }^{15}$

Data yang sudah terkumpul kemudian dianalisis dan dilakukan uji secara statistik dengan menggunakan uji korelasi Spearman dengan $\alpha=5 \%(0,05)$.

\section{HASIL DAN PEMBAHASAN}

\section{Deskripsi Karakteristik Responden}

Pekerja dalam area fabrikasi terbagi menjadi 3 jenis pekerja yaitu fitter, welder, dan helper. Dalam menjalankan proses produksi di area fabrikasi, responden dalam penelitian ini lebih didominasi dengan pekerjaan yang bersifat fisik. Berdasarkan hasil penelitian didapatkan data dari 30 responden yang semuanya berjenis kelamin laki-laki dengan masa kerja 1 bulan hingga 28 tahun dengan rata-rata 6,9 tahun. Deskripsi usia dan Indeks Masa Tubuh (IMT) responden yang terlibat dalam penelitian ini dapat dilihat dalam Tabel 1 berikut.

Tabel 1. Deskripsi Usia dan IMT

\begin{tabular}{llllll}
\hline Variabel & Mean & Median & Min & Max & SD \\
\hline Usia & 35,3 & 35,5 & 20 & 54 & 9,433 \\
IMT & 22,9 & 22,1 & 16,4 & 29,7 & 2,901 \\
\hline
\end{tabular}

Berdasarkan Tabel 1 diatas dapat disimpulkan bahwa rata-rata usia responden mencapai 35,3 tahun. Usia responden termuda dalam penelitian ini adalah 20 tahun dan responden tertua berusia 54 tahun. Rata-rata status gizi (IMT) yang dimiliki responden adalah 22,9 atau normal. Terdapat responden yang memiliki status gisi kurang (IMT $=16,4$ ) dan terdapat responden yang memiliki status gizi gemuk (IMT=29,7). Tidak didapati responden yang memiliki status gizi obesitas (IMT>35).

\section{Analisis Univariat}

Analisis univariat dilakukan pada variabel usia dan status gizi. Analisis kedua variabel independen tersebut dapat dilihat pada Tabel 2 berikut ini:

Tabel 2. Analisis Univariat

\begin{tabular}{|c|c|c|c|}
\hline Variabel & & $\mathrm{n}$ & $\%$ \\
\hline \multirow{3}{*}{ Usia } & $\leq 35$ & 15 & 50,0 \\
\hline & $>35$ & 15 & 50,0 \\
\hline & Total & 30 & 100,0 \\
\hline \multirow{4}{*}{ Status Gizi } & Kurus & 2 & 6,6 \\
\hline & Normal & 20 & 66,7 \\
\hline & Gemuk & 8 & 26,7 \\
\hline & Total & 30 & 100,0 \\
\hline
\end{tabular}

Berdasarkan Tabel 2 diatas dapat disimpulkan bahwa terdapat persamaan proporsi (masing-masing 50\%) antara responden yang $\leq$ 35 tahun dan yang berusia > 35 tahun. Sedangkan untuk status gizi, mayoritas responden dalam penelitian ini memiliki status gizi normal $(66,7 \%)$ dengan nilai Indeks Masa Tubuh (IMT) sebesar 18-24.

\section{Analisis Bivariat}

Hasil analisis bivariat antara variabel usia dengan kelelahan kerja dan status gizi dengan kelelahan kerja dapat dilihat pada Tabel 3 berikut ini. 
Tabel 3. Hubungan Antara Usia dan Status Gizi dengan Kelelahan Kerja

\begin{tabular}{|c|c|c|c|c|c|c|c|c|}
\hline \multirow[t]{3}{*}{ Variabel } & & \multicolumn{4}{|c|}{ Kelelahan kerja } & \multirow{2}{*}{\multicolumn{2}{|c|}{ Total }} & \multirow[t]{3}{*}{$p$-value } \\
\hline & & \multicolumn{2}{|c|}{ Normal } & \multicolumn{2}{|c|}{ Lelah } & & & \\
\hline & & $\mathrm{n}$ & $\%$ & $\mathrm{n}$ & $\%$ & $\mathrm{n}$ & $\%$ & \\
\hline \multirow[t]{2}{*}{ Usia } & $\leq 35$ & 9 & 60,0 & 6 & 40,0 & 15 & 100,0 & \multirow{2}{*}{0,332} \\
\hline & $>35$ & 10 & 66,7 & 5 & 33,3 & 15 & 100,0 & \\
\hline \multirow[t]{3}{*}{ Status Gizi } & Kurus & 2 & 100,0 & 0 & 0,0 & 2 & 100,0 & \multirow{3}{*}{0,716} \\
\hline & Normal & 10 & 50,0 & 10 & 50,0 & 20 & 100,0 & \\
\hline & Gemuk & 7 & 87,5 & 1 & 12,5 & 8 & 100,0 & \\
\hline
\end{tabular}

Berdasarkan Tabel 3 di atas dapat diinformasikan bahwa hasil uji korelasi Spearman antara variabel usia pekerja dengan kelelahan kerja menghasilkan nilai p-value $(0,332)$ lebih besar dari $\alpha(0,05)$ sehingga Ho di terima. Artinya tidak terdapat hubungan yang signifikan antara usia pekerja dengan kelelahan kerja yang dirasakan pekerja.

Hasil penelitian ini sejalan dengan penelitian yang dilakukan pada tenaga kerja di bagian produksi PT. Putra Karangetang Popontolen Minahasa Selatan, ${ }^{16}$ pada pekerja bagian operator Sumber Pengisian Bahan Bakar Umum (SPBU) di Kecamatan Ciputat, ${ }^{17}$ pada pekerja mebel di CV. Mercusuar dan CV. Mariska Desa Leilem Kecamatan Sonder Kabupaten Minahasa, ${ }^{18}$ yang menyatakan bahwa tidak ada hubungan yang signifikan antara usia pekerja dengan kelelahan kerja.

Berdasarkan Tabel 2. hasil penelitian menyatakan bahwa responden yang berusia $\leq 35$ tahun memiliki proporsi yang sama dengan responden yang berusia >35 tahun. Meskipun demikian, prevalensi terjadinya kelelahan kerja pada kelompok responden yang berusia $\leq 35$ tahun lebih besar (40\%) daripada prevalensi kelelahan kerja pada kelompok responden yang berusia $>35$ tahun $(33,3 \%)$. Hal ini tidak sesuai dengan teori yang menyatakan bahwa puncak kekuataan otot pada pekerja mencapai puncak pada usia 25-35 tahun dan mengalami penurunan yang signifikan pada usia 50-60 tahun. ${ }^{4}$

Bekerja merupakan hasil dari kerja sama yang dilakukan oleh sistem syaraf pusat dan perifer serta sistem organ-organ didalam tubuh termasuk peran sistem otot rangka (musculoskeletal). Dalam pekerjaan yang didominasi oleh aktivitas fisik, otot memiliki peran yang sangat penting. Otot bekerja dengan mekanisme kontraksi dan relaksasi. ${ }^{19}$ Untuk mendapatkan kapasitas otot yang maksimum, selain memperhatikan faktor usia juga harus memperhatikan jenis kelamin, konstitusi, latihan-latihan, dan motivasi sesaat. ${ }^{4}$

Meskipun berusia tua, pekerja yang aktif dapat memiliki kemampuan dan kinerja yang sama atau bahkan bisa lebih tinggi dibandingkan dengan pekerja yang memiliki usia lebih muda tetapi tidak aktif. ${ }^{20}$ 
Tidak adanya hubungan antara usia dan kelelahan kerja dalam penelitian ini bisa disebabkan karena beberapa hal seperti proporsi usia $\leq 35$ dan $>35$ yang sama besar. Selain itu, terdapat beberapa faktor lain yang mendukung dan dapat meningkatkan kapasitas pekerja sehingga tidak terjadinya kelelahan kerja antara lain jenis kelamin responden yang seluruhnya laki-laki sehingga memiliki kapasitas otot yang lebih kuat, serta masa kerja yang bervariasi sehingga pekerja sudah terlatih secara otomatis.

Berdasarkan Tabel 3 diatas dilihat bahwa hasil uji korelasi Spearman antara variabel status gizi pekerja dengan kelelahan kerja menghasilkan nilai $p$-value $(0,716)$ lebih besar dari $\alpha(0,05)$ sehingga Ho di terima. Artinya tidak ada hubungan yang signifikan antara status gizi pekerja dengan kelelahan kerja yang dirasakan pekerja.

Hasil penelitian ini sejalan dengan penelitian yang dilakukan pada pekerja konveksi bagian penjahitan di CV. Aneka Garment Gunungpati Semarang, ${ }^{7}$ pada tenaga kerja di bagian produksi PT.Sari Usaha Mandiri Bitung, ${ }^{21}$ Pada tenaga kerja di bagian produksi PT. Putra Karangetang Popontolen Minahasa Selatan, ${ }^{16}$ pada tenaga kerja bongkar muat (TKBM) di Pelabuhan Manado, ${ }^{22}$ dan pada pekerja penjahit sektor usaha informal dikompleks Gedung Presiden Pasar 45 Kota Manado, ${ }^{23}$ menyatakan bahwa tidak ditemukan hubungan yang signifikan antara status gizi dengan kelelahan kerja.
Pekerja yang menjadi responden dalam penelitian ini merupakan pekerja yang berasal dari subkontraktor. Dalam pemenuhan kebutuhan nutrisinya, pekerja mendapatkan makanan dari pihak ketiga (jasa catering) yang ditunjuk oleh perusahaan sehingga jumlah kalori yang diperoleh pekerja tidak diketahui secara. Namun, waktu pemberian makanan dilakukan sudah baik yaitu pada pukul 12.00 atau 4 jam setelah kerja. Hal ini dinilai tepat karena setelah 4 jam pekerja mengalami penurunan kadar glukosa didalam darah sehingga dapat menurunkan tingkat produktivitas pekerja. Sehingga dengan adanya asupan makanan, sumber energi yang dibutuhkan pekerja kembali terpenuhi. Jika kapasitas pekerja seimbang dengan task demand yang diberikan, maka kelelahan kerja tidak terjadi. ${ }^{5,19}$

Berdasarkan Tabel 3 dapat disimpulkan status gizi pekerja dalam keadaan yang cukup baik. Hal itu ditandai dengan jumlah status gizi pekerja yang mayoritas dalam tingkatan normal $(66,7 \%)$. Meskipun demikian prevalensi terjadinya kelelahan kerja pada pekerja yang memiliki status gizi normal justru lebih besar (50\%) jika dibandingkan dengan pekerja yang yang memiliki status nutrisi kurang $(0 \%)$ maupun yang memiliki status gizi lebih (12,5\%).

Secara fisiologis, tubuh manusia dapat dianalogikan sebagai mesin yang membutuhkan bahan bakar dalam bentuk energi untuk bekerja. Kelelahan kerja terjadi berkurangnya cadangan energi dan meningkatnya sisa metabolisme 
berupa asam laktat didalam peredaran darah akibat sisa metabolisme yang berdampak pada menurunya kinerja otot-otot tubuh dan perubahan arus listrik pada sistem syaraf. ${ }^{4,5}$

Status gizi yang baik dengan jumlah asupan kalori dalam jumlah dan waktu yang tepat berpengaruh secara positif terhadap kapsitas pekerja. Apabila asupan kalori tenaga kerja tidak sesuai dengan kebutuhannya maka tenaga kerja tersebut akan lebih cepat merasakan lelah dibandingkan dengan tenaga kerja yang asupan kalorinya memadai. ${ }^{7}$

Banyak sedikitnya jumlah kalori yang dibutukan pekerja dipengaruhi oleh beberapa hal antara lain ukuran tubuh, tinggi badan, berat badan, usia, jenis kelamin, kegiatan sehari-hari, beban kerja, dan lingkungan kerja seperti iklim kerja. ${ }^{4}$

Tidak adanya hubungan yang signifikan antara status gizi dan kelelahan kerja yang dialami oleh para pekerja dalam penelitian ini dapat terjadi akibat jumlah asupan kalori. Meski tidak diketahui secara pasti, berdasarkan teori diatas kelelahan dapat terjadi ketika asupan kalori yang diterima pekerja tidak sesuai dengan kebutuhan energi yang harus dikeluarkan ketika bekerja.

Terdapat beberapa keterbatasan dalam penelitian ini, salah satunya adalah peneliti tidak menghitung asupan kalori sehingga tidak diketahui secara pasti jumlah kalori yang didapatkan pekerja dengan kebutuhan yang harus dipenuhi.

\section{SIMPULAN DAN SARAN}

\section{Simpulan}

Simpulan yang dapat diambil dalam penelitian ini adalah tidak ada hubungan yang signifikan antara usia dan status nutrisi dengan kelelahan subjektif yang dialami pekerja. Nilai p-value yang dihasilkan untuk variabel usia adalah 0,332 dan untuk variabel status gizi adalah 0,716 .

\section{Saran}

Perusahan perlu mempertahankan pengorganisasian tenaga kerja dengan memperhatikan usia pekerja agar tidak terjadi kelelahan. Perusahaan juga perlu mempertahankan status gizi pekerja baik dilakukan dengan menjaga asupan kalori yang diberikan kepada pekerja maupun dengan membuat program program kebugaran fisik sehingga status gizi lebih yang dialami pekerja bias kembali dalam status normal.

\section{REFERENSI}

1. Badan Pusat Statistik. Indikator Industri Manufaktur Indonesia 2015. Jakarta; 2015. https://www.bps.go.id/publication/2017/10/ 10/481781472c99d522335a4a57/indikatorindustri-manufaktur-indonesia-2015.html.

2. International Labour Organization (ILO). Laporan Ketenagakerjaan Indonesia 2017 : Memanfaatkan Teknologi Untuk Pertumbuhan Dan Penciptaan Lapangan Kerja.; 2017. http://www.oit.org/wcmsp5/groups/public/--asia/---ro-bangkok/---ilojakarta/documents/publication/wcms_6136 26.pdf.

3. Safe Work Australia. Guide For Managing 
The Risk Of Fatigue At Work. 2013. https://www.safeworkaustralia.gov.au/syste $\mathrm{m} /$ files/documents/1702/managing-therisk-of-fatigue.pdf.

4. Maurits LSK. Selintas Tentang Kelelahan Kerja. Yogjakarta: Amara books; 2010.

5. Tarwaka. Ergonomi Industri Dasar-Dasar Pengetahuan Ergonomi Dan Aplikasi Di Tempat Kerja. Surakarta: Harapan Press; 2013.

6. Salasa N, Kolibu F, Punuh M. Hubungan Antara Umur, Masa Kerja Dan Status Gizi Dengan Kelelahan Kerja Pada Pekerja Di Bagian Loining PT . Sinar Pure Foods Internasional Bitung. 2017. http://www.ejournalhealth.com/index.php/ medkes/article/download/364/355.

7. Atiqoh J, Wahyuni I, Lestantyo D. FaktorFaktor yang Berhubungan dengan Kelelahan Kerja pada Pekerja Konveksi Bagian Penjahitan di CV. Aneka Garment Gunungpati Semarang. J Kesehat Masy UNDIP. 2015;17(1):13-20. https://media.neliti.com/media/publications /18340-ID-faktor-faktor-yangberhubungan-dengan-kelelahan-kerjapada-pekerja-konveksi-bagi.pdf.

8. Damopoli ML, Josephus J, Ratag BT. Hubungan Antara Umur Dan Beban Kerja Terhadap Kelelahan Kerja Pada Tenaga Kerja Bongkar Muat Di Pelabuhan Samudera Bitung. 2015. https://ejournalhealth.com/index.php/CH/ar ticle/download/602/590.

9. Andriani KW. Hubungan umur, kebisingan dan temperatur udara dengan kelelahan subjektif individu di PT X Jakarta. Indones J Occup Saf Heal. 2016;5(2):112-120. https://ejournal.unair.ac.id/IJOSH/article/view/417 8.

10. Tarwaka, Bakri SHA, Sudiajeng L. Ergonomi Untuk Keselamatan, Kesehatan Kerja Dan Produktivitas. Edisi 1. Surakarta: Uniba Press; 2004. http://shadibakri.uniba.ac.id/wp-
content/uploads/2016/03/Buku-

Ergonomi.pdf.

11. Pranoto BA, Hardjanto, Suwadji. Hubungan Status Gizi Dengan Kelelahan Kerja Pada Tenaga Kerja Bagian Weaving Di Pt. Iskandar Indah Printing Textile Surakarta. J Progr Stud Kesehat Masy - FIK Univ Muhammadiyah Surakarta. 2014. http://eprints.ums.ac.id/32389/10/NASKA H PUBLIKASI.pdf.

12. Sari AR, Muniroh L. Hubungan Kecukupan Asupan Energi dan Status Gizi dengan Tingkat Kelelahan Kerja Pekerja Bagian Produksi (Studi di PT. Multi Aneka Pangan Nusantara Surabaya). Amerta Nutr. 2017;1(4):275. doi:10.20473/amnt.v1i4.2017.275-281.

13. Monspub TP. Dasar Nutrisi Kedokteran: Gizi Lebih Mudah Dipahami. JILID 1. Makasar: Penerbit Monspub; 2016.

14. Riyadi ALS. Ilmu Kesehatan Masyarakat. Yogyakarta: ANDI; 2016.

15. Zuraida R, Chie HH. PADA RESPONDEN DI INDONESIA Rida Zuraida; Ho Hwi Chie. 2014;5(9):1012-1020. http://journal.binus.ac.id/index.php/comtec h/article/viewFile/2357/1783.

16. Chesnal H, Rattu AJM, Lampus BS. Kelelahan Kerja Pada Tenaga Kerja Di Bagian Produksi PT. Putra Karangetang Popontolen Minahasa Selatan. 2015. http://fkm.unsrat.ac.id/wpcontent/uploads/2015/02/jurnal-HandiChesnal.pdf.

17. Faiz N. Faktor-Faktor Yang Berhubungan dengan Kelelahan Kerja Pada Pekerja Bagian Operator SPBU di Kecamatan Ciputat. 2014. http://repository.uinjkt.ac.id/dspace/bitstrea m/123456789/26124/1/NURLI FAIZfkik.pdf.

18. Melati S. Hubungan Antara Umur, Masa Kerja Dan Status Gizi Dengan Kelelahan Kerja Pada Pekerja Mebel Di Cv. Mercusuar Dan Cv. Mariska Desa Leilem 
Kecamatan Sonder Kabupaten Minahasa. 2013;(I). http://fkm.unsrat.ac.id/wpcontent/uploads/2013/08/Jurnal-SriniMelati-091511186-KESKER.pdf.

19. Suma'mur. Higiene Perusahaan Dan Kesehatan Kerja (HIPERKES). Edisi 2. Jakarta: Sagung Seto; 2013.

20. Barth RC, George PD, Hill RH. Environmental Health and Safety for Hazardous Waste Sites. Vol 2. Virginia: AIHA Press; 2007. doi:10.1523/JNEUROSCI.3468-13.2013.

21. Malonda AA, Kawatu PAT, Nancy S.H. Malonda. Hubungan Antara Umur, Waktu Kerja Dan Status Gizi Dengan Kelelahan Kerja Pada Tenaga Kerja Di Bagian Produksi Pt.Sari Usaha Mandiri Bitung. $2015 . \quad$ http://fkm.unsrat.ac.id/wpcontent/uploads/2015/05/ANGGI-

JURNAL-1.pdf.

22. Garedja C, Malonda NSH, Doda V. Hubungan Antara Status Gizi Dengan Kelelahan Kerja Pada Tenaga Kerja Bongkar Muat (Tkbm) Di Pelabuhan Manado. 2017;649:1-7. http://www.ejournalhealth.com/index.php/ medkes/article/download/348/339.

23. Kroons R, Rattu AJM, Josephus J. Hubungan Antara Masa Kerja, Status Gizi Dan Lama Kerja Dengan Kelelahan Kerja Pada Pekerja Penjahit Sektor Usaha Informal Di Kompleks Gedung President Pasar 45 Kota Manado. 2014. http://fkm.unsrat.ac.id/wpcontent/uploads/2014/11/rensi.pdf. 